\title{
Research on Impacts and Countermeasures of Korean Culture on National Culture of Our Country
}

\author{
Shu $\operatorname{Jin}^{1}$, Guangda $X u^{2}$ \\ ${ }^{1}$ Foreign Languages College, Beihu University, Jilin, 132013, China \\ ${ }^{2}$ Orthopedics Department, People’s Hospital of Jilin City, Jilin,132013, China
}

Keywords: Korean culture, National culture, Cultural impact

\begin{abstract}
Korean culture, headed by Korean dramas, has achieved both economic and cultural success in the Asian market as a whole. The national culture of our country has been strongly impacted in this process. This paper analyzes the manifestations of the impact of our national culture, and puts forward corresponding countermeasures and suggestions to protect and promote our national culture.
\end{abstract}

\section{Introduction}

In recent years, Korean culture, represented by film and television and popular music, has been rapidly rising in East Asia and has been spreading for a large and long time in the mainland of china. As a capitalist mass consumption culture, the strong tide of Korean wave has greatly impacted the development of China's cultural industry, so that China's cultural security is beginning to face serious practical challenges and potential threats. However, due to China's long-term adherence to the basic national policy of economic construction will, as well as military security and political security as the core of the traditional concept of security, culture security culture shock, including South Korea and has not received enough attention, in Korean culture struck after a long period of time, no take timely and effective measures, resulting in cultural sovereignty and interests has been severely violated to a great extent, the development of cultural industry is gradually entering the security dilemma difficult. The abundant cultural treasures have five thousand years of history of civilization. 5000 years of accumulated Chinese each is the pride of Chinese people, Chinese is different from other ethnic Chinese in the world according to, is the forest of independent, calm and confident standing position. In recent years, the impact force of Korean culture and foreign culture in all over the Chinese. It set off a wave of heat waves in China, forming a Korean wave. The Chinese, who have always been culturally confident, feel the pressure to face the Korean wave, and the Chinese people are exposed to the potential unrest of the Korean wave culture to make them accept different positions and accept opinions. In the context of cultural pluralism, what attitude China should take to deal with the Korean wave culture has become an important topic.

\section{Impacts of Korean Culture on National Culture of Our Country}

Change Cultural Life Approach. Consumer culture is a consumption pattern that is mainly not for the purpose of satisfying the basic needs of life in the postindustrial society, the western developed capitalist countries. The life style is deeply influenced by the construction of aesthetic taste and taste. It tries to lead the economic activities of consumption by tempting consumption, chasing consumption and conspicuous consumption. Its emphasis is not on the value of goods, but on the value of symbols. For example, buy food to eat but not to lose weight. Buying clothes is not for show, but for showing the figure. People, especially young people, are very concerned about their way of life, pay attention to the similarities and differences between their own consumption patterns and the world trends, so as to imitate or even follow the trend of morbid. Korean culture is a typical 
mass consumption culture. It is easy, natural, warm and leisurely. It is easy for young people to seek novelty and wonder. With the popularity of the Internet, the costumes, diet and living habits of the Korean film and TV drama may have swept our country overnight. And the handsome boys and girls in Korean dramas are mostly wearing fashionable brands and buying high-grade consumer goods. Over time, this extravagant consumption culture has a bad influence on the consumption enthusiasm, consumption desire, consumption habit and consumption behavior of our audience, especially teenagers, and changes their life style. Market rules believe that consumption guide production. If China's consumers to develop Korean consumption habits and lifestyle, it will inevitably force our cultural production, have to adapt to this undesirable consumer habits.

Grab Cultural Market Share. The development of Korean culture is full of commercial and industrial objectives. But as a cultural industry, its development cannot get rid of the influence and restriction of the political environment. The Korean government not only regards the cultural industry as an important pillar industry to develop the economy, but also attaches great importance to the role of the cultural industry in the protection and promotion of national culture. The South Korean government has a more forward-looking understanding of the protection and promotion of national culture in twenty-first century, a powerful cultural power would become an economic powerhouse.". If a country cannot create its own cultural content and make its own cultural resources inadequate, it will experience a serious cultural independence crisis. It is aware of the importance of national culture development, and aware of this basic truth offense is the best defense, the South Korean government to spare no effort to the Korean cultural industry with the Korean led policy and fund support in many ways, for example, the establishment of export incentive system, the establishment of overseas marketing network, take the Korean film to participate in the 9 World Film Festival. All the expenses, these measures provide a strong political and economic backing for the overseas market. This will not only ease the contradiction of small domestic market, consumption capacity is limited, and can output through a lot of drama, the audience Chinese makes hundreds of millions of large outputs of Korean dramas, so that hundreds of millions of China audience have more understanding of the Korean national culture. Through the cooperation between government and industry, not only to achieve a breakthrough in South Korea's exports of cultural products, but also realize the ideology quietly penetrated the birthplace of Confucianism, for Chinese, this is a kind of sad.

Impact on Youth's Values. The South Korean film and television actor in the beautiful screen, decent fashion dress, shooting the beautiful scenery, beautiful music, has played a positive role in cultivating students' aesthetic taste and aesthetic taste. Moral educators can organize topic, let the students discuss; elective courses can some movie reviews such as colleges and universities, which relates to the Korean drama review, guide students to focus on the positive aspects of film culture in South Korea. At the same time, we cannot ignore the negative impact of Korean film and television culture. The aesthetic culture embodied in Korean film and television culture often focuses on visual enjoyment and sensory stimulation, ignoring spiritual cultivation and sublimation of wisdom. While seeing the positive aspects of Korean film and television culture, students should also pay attention to their shortcomings and consciously resist some of them. In recent years, the rise of horror films and horror films in Korea has also risen. The horror film is a carrier of social reality in many dark, evil, contradiction and crisis and an ultimate catharsis, the people more harm than benefit is an indisputable fact. There are a lot of people, after the horror film will appear emotional and behavioral abnormalities, insomnia, and there are people on the spot scared halo or cerebrovascular rupture, leading to death. In fact, violence or horror movies are limited in Korea, not to everyone. But these films, through the Internet or illegal means, have no hindrance to get into the vision of domestic college students. This kind of film shows the ugliness and desire of human beings thoroughly, and this kind of film will lead to psychological misleading for college students, and is not conducive to the formation of correct values. 


\section{Countermeasures of Korean Culture on National Culture of Our Country}

Enhance Cultural Self-Confidence. Support artists produced with the times and practical content, excellent cultural products have Chinese characteristics and style; promote the quality strategy, support the original culture, encourage the creation of realistic themes, Ever fount the introduction of cultural products. The goal of constructing a modern cultural industry system is that the categories are comprehensive, the structure is reasonable, the technology content is high, the creativity is good and the competition power is great. Promoting the adjustment of cultural industry structure. On the one hand, we should actively develop and publish traditional cultural industries such as publishing, film and television, advertising, entertainment, printing, exhibition and so on. On the other hand, we need to speed up the development of new cultural industries, including digital publishing, cultural creativity, animation, games and mobile multimedia. Cultivate cultural brands. Strengthen the protection of intellectual property rights, bigger and stronger to carry forward the excellent national cultural enterprises, with the core competitiveness of the enterprise culture, spare no effort to build a well-known brand, the brand of cultural products of the world-famous Chinese. At the same time, we should actively promote mergers and acquisitions by competitive cultural enterprises and support them in the implementation of cross - industry, trans regional and inter ownership restructuring. The advantage of network video is that it breaks through the mode of communication, and can freely and freely choose the content of consumption and the time of watching. As in video entertainment, do not follow what you see, follow what you see, not to follow the crowd, to clearly understand their own specific circumstances, not blind pursuit. Learn to think before you leap, have your own opinions and personality, take the essence, discard the dross, and create a good atmosphere for personal consumption. Only in this way, a small group of individual college students can have a clear and comfortable visual consumption atmosphere. Support the integration of cultural industries and related industries, and raise the cultural content and cultural value of related industries.

Borrow Advanced Experience. We assume that can temporarily divided to culture and should be rejected according to the cultural needs, how to put the essence of culture to a proper extent will be extracted in practice facing another problem. Culture is holistic and divisibility. Its divisibility refers to the cultural hierarchy, namely, the level of the utensil, the system level and the spiritual level, but not the extraction. Culture is a whole, and any part of it is a part of the whole, and the part that is divorced. The impact of the Korean wave on China's economic and cultural markets is a driving force for the development of China's economic and cultural market and a new element for updating and restructuring. The essence of dross that we distinguish seems to be the same fate, it is difficult to separate. The protection of Korean traditional culture has been recognized all over the world, and it is closely related to the vigorous protection of the Korean government. Specifically, the main coverage is as follows. Conduct cultural legislation. As early as the 50s of last century, the Korean government enacted and promulgated the law on the protection of cultural heritage, providing a legal basis for the protection of cultural heritage. Raise people's awareness of cultural heritage protection. The Korean government has put forward the slogan of "understanding, finding and managing the cultural heritage - the soul of our nation". Ensure financial support. For example, the government offers special subsidies to traditional artists to avoid the loss of traditional crafts. Investment to protect historical and cultural relics. Allocate special funds, hold cultural heritage and other activities, and publicize their own traditional culture to the world. Attach importance to traditional holidays. South Korea has 15 days of statutory holidays every year. During the holidays not only implement national holiday, the national government also asked friends and family reunion, encourage people to wear hanbok, worship, National Games, making the traditional cakes.

Develop cultural Diplomacy. One of the most important reasons why Korea has developed from a culturally disadvantaged country to a culturally strong country in the short run is that the Korean government attaches importance to cultural diplomacy. And Korean culture and other foreign strong cultural contest, which cannot blindly defensive, must be passive to take the initiative, take the "go out" strategy. Broaden the platform for international cultural exchanges. At present, the world does not know much about Chinese culture, and many of them are one-sided, distorted and erroneous. For 
the need to actively expand the international exchange platform, with the International Fashion Festival, International Film Festival, the world horticultural exposition, new agricultural products fair culture exhibition, and held the International Symposium on academic exchanges, promotion of Chinese culture. At the same time, should actively encourage and support domestic cultural enterprises to go overseas investment, to enter the international market of mainstream culture, on the one hand the rich and colorful Chinese culture demonstrate to the world, but also can speak profound cultural resources of our country into a powerful cultural competitive advantage. Strengthening the construction of Confucius institute. Confucius and Confucius not only become the world class area public platform for learning Chinese, but also become the promotion of his country to understand China's window of culture. Under the new situation, we should make good use of the role of Confucius Institute and Confucius classroom as an overseas cultural dissemination position. On the one hand, we must vigorously promote the teaching of Chinese, on the other hand, more important is to teach language at the same time, let the people of the world understand more, and accept extensive and profound Chinese culture. Part $\mathrm{H}$ participation in the formulation of international cultural and technical standards. Taking technical standard as trade barrier is an important form and characteristic of international competition. At present, the global cultural and technical standards are controlled by the United States and other Western countries. Therefore, we must take an active part in the formulation of international cultural and technical standards and establish more equitable and reasonable international cultural and technical standards.

\section{Conclusion}

Korean culture has gradually become the main trend of mass culture communication in China, and its influence and function on the surrounding society is more and more big. There are both positive and negative aspects. Facing the impact of Korean culture on our national culture, we must strengthen cultural self-confidence, create cultural products, carry out cultural output, and resist the adverse effects of Korean culture.

\section{Acknowledgements}

The research is the result of "Planning Project of Philosophy and Social Science Foundation of Jilin Province” named "Research on Implications of Korean Policy of Small-scale Schools Merging on Canceling Teaching Centers and Merging Rural Primary Schools in Our Country” (Grant No. 2014B71), "Project of Social Science Association of Jilin" named Research and Reference of College Employment Guidance in Korea” (Grant No. 1618-2 of United Provinces) and "Project of Social Science Association of Jilin” named Implications of Reuse of Abandoned Primary School Buildings of Korea on Canceling Teaching Centers and Merging Rural Primary Schools in Our Country. All the above projects all led by Jin Shu.

\section{References}

[1] Yang Hongqin. Study of Network Visual Cultural Transmission's Impact on College Students' Visual Consumption- Case Study of Korean TV Series Drama's Infl uence Online [J]. Journal of Guangzhou Open University, 2013(2): 71-74+110.

[2] Tian Le. The Impact of South Korean Screen Culture on College Students Value in China [J]. Journal of Hainan Normal University (Social Sciences), 2014, 27(3): 107-110.

[3] Wei Jingxia. Korean Culture's Influence on Chinese National Culture and Some Strategies Concerning it [J]. Journal of Zhongzhou University, 2009, 26(1): 78-80.

[4] Du Li. A Brief Analysis of Chinese Acceptance Attitude on the Korean Culture [J]. Journal of Shaanxi Xueqian Normal University, 2016, 32(12): 6-10. 